\title{
Monitoring in the Treatment of Patients with Aneurysmal and Nonaneurysmal Subarachnoid Haemorrhage in Terms of Nursing Care and Therapy
}

1 Mirsada Čustović

${ }^{1}$ Clinic for Lung Diseases and Tuberculosis „Podhrastovi", University of Sarajevo Clinical Centre, Sarajevo, Bosnia and Herzegovina

Article received: 02.07.2018.

Article accepted: 26.11.2018.

DOI: $10.24141 / 2 / 3 / 1 / 1$

Author for correspondence:

Mirsada Čustović

Clinic for Lung Diseases and Tuberculosis „Podhrastovi"

University of Sarajevo Clinical Centre, Sarajevo,

Bosnia and Herzegovina

E-mail: custovicm@gmail.com

Keywords: subarachnoid haemorrhage, aneurysm, monitoring, neurosurgical nurse pre and postoperative care, vasospasm, nosocomial infections and complications

\section{Abstract}

Cerebrovascular diseases together with cardiovascular and malignant diseases are the most common diseases in the developed world, regardless of the gender. They are at the third place as the cause of mortality and first as the cause of disability.

Subarachnoid haemorrhage is a condition of discharging blood from cerebral arteries into the subarachnoid space within the brain. Subarachnoid haemorrhage $(\mathrm{SAH})$ has a number of etiological features, but when it comes to spontaneous subarachnoid haemorrhage, in $80 \%$ of the cases it is caused by the rupture of an intracranial aneurysm. Subarachnoid haemorrhage $(\mathrm{SAH})$ can be spontaneous and traumatic (post-traumatic). Also, it could be primary (direct bleeding into the subarachnoid space) or secondary (parenchymal bleeding to the subarachnoid space of the brain).

Cerebral aneurysms are a local expansion in the blood vessel wall usually at the bifurcation of the artery. If cerebral artery ruptures and blood enters the subarachnoid space, the patient can have a very strong headache at the back and front part of the head. Short term memory can be affected as well.

The initial assessment of patients should include: an overview of the quantitative state of mind, pupil size and reaction to light, motor and sensory function, the presence of headaches, dysfunction of cranial nerve (ptosis of the eyelids, difficulty moving eyes in all directions) blurred vision, aphasia, other neurological deficits). 
Several serious complications often arise after a successful operative treatment of the subarachnoid haemorrhage and aneurysm. One such complication is cerebral vasospasm, and is present in 50 to $70 \%$ of the patients. Late complications include recurrent bleeding, brain edema, chronic hydrocephalus and as most important - brain infarction.

The incidence of subarachnoid haemorrhage ranges from $10-15 / 100000$ inhabitants. About $20 \%$ of the patients with spontaneous subarachnoid haemorrhage are younger than 45 years, while patients older than 70 years have a less positive prognosis of survival. Spontaneous subarachnoid haemorrhage is a disease of the middle age (55-60 years) with a relatively high mortality and morbidity. The prevalence of patients with an intracranial aneurysm is unknown, but it is assumed to be of higher incidence than subarachnoid haemorrhage. Approximately 10$15 \%$ of the patients die before they reach the physician, $10 \%$ die within the first few days, while the mortality rate in patients with all forms of subarachnoid haemorrhage is up to $45 \%$.

Morbidity is significant, considering that $66 \%$ of the patients never return to their earlier work, nor they have the same quality of life. Most patients with subarachnoid haemorrhage are subjected to a microneurosurgical treatment.

In monitoring the patients and depending on the complications, but also in all situations, the role of nurses is primarily reflected in monitoring vital parameters and states of consciousness, and recognizing the signs and symptoms of neurological deterioration of the patient.

Hypothesis. Patients with proper postoperative nursing care, monitoring and rehabilitation, with aneurysmal and nonaneurysmal subarachnoid haemorrhage, have fewer complications such as neurological deficits, pressure ulcers, nosocomial infections, changes in the values of the vital parameters and biohumoral status.

Research Objectives. To show the total number of operated patients with confirmed subarachnoid haemorrhage at the Department of Neurosurgery, University of Sarajevo Clinical Centre during the period from 1 January 2013 to 31 December 2014. To show the ways in which the patients were monitored from admission to discharge from the Department. To show the stages of the patients' progress along with the outcome of the treatment strategy. To show quality indicators (ventilator-associated pneumonia, nosocomial infections, pressure ulcers) in the test sample.

Research Method. The research was a retrospective study. A descriptive analytical method was used which compared the data from the patient medical histories that included physicians and nurses' notes for patients that were operated on at the Department of Neurosurgery, University of Sarajevo Clinical Centre. The sample included patients of both genders with a confirmed diagnosis of subarachnoid haemorrhage (aneurysma cerebri, haemorrhagia subarachnoidalis spontanea) who were operated on at the Department of Neurosurgery, University of Sarajevo Clinical Centre, in the period from 1 January 2013 to 31 December 2014. Of the 142 respondents, 93 or $65.5 \%$ were hospitalized for aneurysmal surgery and a control group of 49 of them, or $34.5 \%$, were operated on for nonaneurysmal subarachnoid haemorrhage. There were $50.7 \%$ of men $(n=72)$, and $49.3 \%$ of women $(n=70)$. The participants in the study were of the average age of 54 years or $45-63.2$ years. The study did not include the education and occupation of the participants.

Criteria for inclusion into the study: Patients with a confirmed diagnosis of subarachnoid haemorrhage; patients operated on during the abovestated period; people older than 18 years.

Criteria for exclusion from the study: Patients who were in the abovestated period diagnosed with the same illness and have not undergone surgery, but underwent conservative neuroradiological treatment (embolization).

Results. Of the 142 respondents in the sample, 65.5\% were hospitalized for aneurysmal surgery and 34.5\% of the patients were operated for nonaneurysmal subarachnoid haemorrhage. The respondents were on average 54 years old. Men were on average 53 years and women 55 years old. Aneurysmal subarachnoid haemorrhage was more frequent among women (65.6\%). The respondents with nonaneurysmal subarachnoid haemorrhage were older, 61 (43-62) years. Only $2 \%$ of the patients after aneurysm surgery were not under non-invasive monitoring, while the percentage of those with surgical treatment of nonaneurysmal subarachnoid haemorrhage was significantly higher at $24.5 \%$.

There was a fatal outcome in a total of 30 (32.6\%) patients operated on for an aneurysm while the percentage of those who were operated on due to nona- 
neurysmal haemorraghe was lower and amounted to 4 (8.2\%). Surviving patients, those with an aneurysm, on average stayed in hospital for 18 (12-24) days. Of the total number of patients operated for an aneurysm - $44(47.3 \%)$ were independently mobile after surgery, 9 (9.7\%) had limited mobility, 8 (8.6\%) had very limited mobility and 32 (34.4\%) were immobile.

Most participants operated for subarachnoid haemorrhage were independently mobile after surgery 32 (65.3\%), 10 (20.4\%) had limited mobility, 3 (6.1\%) had very limited mobility and only $4(8.2 \%)$ were immobile. Of the entire sample with aneurysmal haemorrhage, ventilator-associated pneumonia was found in 9 patients (9.7\%) who were operated for an aneurysm and in 2 patients (4.1\%) after SAH surgery.

\section{Introduction}

Neurosurgery is a very complex and specific surgical branch which because of its complexity requires a high degree of specific knowledge and skills in the field of nursing care (1). Subarachnoid haemorrhage $(\mathrm{SAH})$ is the result of bleeding into the subarachnoid space, the space between the brain membranes. Subarachnoid haemorrhage has a number of etiological features, but when it comes to spontaneous subarachnoid haemorrhage, in $80 \%$ of the cases it is caused by a rupture of an intracranial aneurysm (1). Intracranial aneurysms are local expansions in the blood vessel wall usually at the bifurcation of the artery (2). Aneurysmal subarachnoid haemorrhage is indeed a separate entity for its specific etiology and severity of clinical outcome, high rates of morbidity and mortality, characteristic complications related to secondary brain phenomena, and comprehensive therapeutic approach, which implies the almost inevitable microneurosurgical or endovascular treatment (3).

The role of the neurosurgical nurse as one link in a large team of health care professionals involved in the treatment of these patients - in the care and monitoring of the patients with intracranial haemorrhage - is great, unquestionable and well-defined, and to some extent very specific (3). Intracranial aneurysm with and without subarachnoid haemorrhage is a significant health problem. The overall incidence is approxi- mately 9/100 000 inhabitants with a broad range, and in some countries, $20 / 100000$. The incidence is much higher in Finland (19.7 per 100000 inhabitants) and Japan (22.7 per 100000 inhabitants), but not Eastern and Central America (4.2 per 100000 inhabitants). Ruptured aneurysms are the most common cause of spontaneous subarachnoid haemorrhage (about 85\% of the cases). On average, $8 \%$ to $12 \%$ of the patients with sudden headache have SAH.

The mortality rate with conservative treatment during the first months is $50-60 \%$. Morbidity is significant and $66 \%$ of the patients never return to their earlier work, nor have the same quality of life (4). About one third of most of the patients with untreated aneurysm will die of recurrent bleeding within 6 months after the first bleeding (5). Studies name the following risk factors for the formation of an aneurysm and subarachnoid haemorrhage: smoking as the most common risk factor, and as less common consumption of alcohol, hypercholesterolemia and diabetes. Data on hypertension as a risk factor is currently controversial (6).

Subarachnoid haemorrhage can be spontaneous and traumatic (post-traumatic). Also, it can be divided into primary (direct bleeding into the subarachnoid space), or secondary (parenchymal bleeding entering the subarachnoid space of the brain) (7).

The initial assessment of patients includes: an overview of the quantitative state of mind, size of the pupils and reaction to light, motor and sensory function, the presence of headaches, dysfunction of cranial nerves (ptosis of the eyelids, difficulty moving the eye in all directions), blurred vision, aphasia, other neurological deficits (8).

Several serious complications often arise after a successful operative treatment of subarachnoid haemorrhage and aneurysm. One such complication is the cerebral vasospasm, occurring in 50 to $70 \%$ of the patients (9). Cerebral vasospasm occurs 3-4 days after the beginning of subarachnoid haemorrhage and reaches its maximum between days 7 and 10 . About $50 \%$ of these patients suffer from severe neurological symptoms such as decrease in strength, loss of consciousness, loss of ability to speak. Late complications include recurrent bleeding, brain edema, chronic hydrocephalus and the most severe - infarction of the brain (10).

Due to the continuous contact with the patient, the neurosurgical nurse has the responsibility to create a 
baseline assessment and notice the subtle and acute changes in patients with subarachnoid haemorrhage.

At the moment of the patient admission in the intensive care unit, preoperative preparation is to ensure the best possible physical, psychological, social and spiritual readiness for surgical intervention. This is the objective for all members of the health care team. Neurosurgeon and a nurse obtain informed consent from the patient, if their state of mind allows for it, or from a close family member (1).

The nurse should include the patient in the planning and implementation of nursing care, which will help the patient gain confidence, ask questions, express their insecurity and fears, all of which contributes to the successful preparation for the neurosurgical intervention. Nursing care of neurosurgical patients in the early postoperative period is focused on the monitoring of the patient's condition and recognition of complications (1).

The incidence of subarachnoid haemorrhage ranges from $10-15 / 100000$ inhabitants. About $20 \%$ of patients with spontaneous subarachnoid haemorrhage are younger than 45 years, while patients older than 70 years have poorer outcomes. Spontaneous subarachnoid haemorrhage is a disease of the middle age (55-60 years) with a relatively high mortality and morbidity (11). The prevalence of patients with intracranial aneurysms is unknown, but it is assumed there is a higher incidence of subarachnoid haemorrhage. Among European countries the largest incidence is in Finland, 15,1-29.8/100 000 inhabitants, and the lowest in France, 2.2/ 100 000 . Approximately $10-15 \%$ of the patients die before they reach the physician, $10 \%$ die within the first few days, while the mortality rate in patients with all forms of subarachnoid haemorrhage ranges at $45 \%(12)$.

In the monitoring and care of these patients there are specific requirements depending on whether it is a pre or postoperative period, and depending on the resultant complications but also in all situations, the role of the neurosurgical nurse is primarily reflected in the monitoring of vital parameters and conditions of consciousness, and in recognizing the timing of clinical neurological deterioration (13).

Neurosurgical nurses in a neurosurgical unit, intensive care and step-down neurosurgical unit use the following methods:
Neurological assessment:

1. pupils: isocoric, anisocoric;

2. tightness of the neck muscles;

3. expression and understanding of speech;

4. asymmetry of the face, extremities, gait disorder;

5. cognitive alteration (memory, appropriate conversation, understanding of general concepts and situations).

Monitoring of vital parameters:

1. oxygen saturation, blood pressure;

2. cardiac rhythm and frequency;

3. body temperature;

4. respiratory rate.

The assessment of the states of consciousness as well as identifying the occurrence of a neurological deficit by a neurosurgical nurse are extremely important features in the accurate and rapid treatment by a neurosurgeon that often saves life of the patients (14).

\section{Diagnosis of subarachnoid haemorrhage}

The diagnosis of subarachnoid haemorrhage is based on the characteristics of specific clinical symptoms:

- unusual intense headache - "the worst headache ever", consequently, the loss of consciousness, nuchal rigidity, all signs of increased intracranial pressure;

- blood thinged intracranial fluid;

- confirmation of blood in subarachnoid spaces by CT.

It is estimated that $8 \%$ to $12 \%$ of the patients with a sudden headache have SAH. Most cases are confirmed by unenhanced computed tomography. In patients with a negative CT scan, lumbar puncture is performed in order to search for evidence of hemoglobin in the cerebrospinal fluid (15).

In the late 1980s - and early 1990s - it was estimated that about $2 \%$ of the patients with subarachnoid haemorrhage had normal findings by a CT scan of the 
brain if performed within 12 hours from the beginning of the headache (16). Only 3\% of the patients with subarachnoid haemorrhage had a negative computed tomography in the first 24 hours. Today, the lumbar puncture is performed when the scan is normal, and the patient had a sudden intense headache that suggests subarachnoid haemorrhage (17).

Catheter angiography, as an additional method, should be performed in patients with negative CT findings and suspicious lumbar puncture, especially in the presence of blood in the spinal fluid (18).

In patients with unproven aneurysm as a cause of subarachnoid haemorrhage angiography should be repeated to detect a potential source of bleeding and to prevent recurrence of bleeding (19).

\section{Clinical characteristics of subarachnoid haemorrhage}

Cerebral aneurysms are a local expansion in the blood vessel wall usually at the bifurcation of the artery. If cerebral artery ruptures and blood enters the subarachnoid space, the patient can have a very strong headache at the back and front part of the head. It can also cause a short-term loss of consciousness (20). If blood enters the brain parenchyma and basal ganglia it can affect the state of awareness, and can lead to a state of deep coma and rapid lethal outcome. If the awareness is preserved, headaches become diffuse. Further clinical state depends on the course of the disease, which depends on other changes, such as the occurrence of vasospasm, recurrent bleeding, the condition of the cardiovascular system, the patient's age and other (21).

The initial assessment of patients includes: an overview of the quantitative state of mind, size of the pupils and reaction to light, motor and sensory function, the presence of headaches, dysfunction of cranial nerve (ptosis of the eyelids, difficulty when moving the eyes in all directions), blurred vision, aphasia, other neurological deficits (22).

\section{Complications after haemorrhage surgery}

Subarachnoid haemorrhage can lead to devastating outcomes for patients, including the cognitive decline, cerebral vasospasm, and slow cerebral ischaemia.

The main mechanisms that contribute to the expansion of the injury after subarachnoid haemorrhage are poorly understood, therefore, the number of the efficient pharmaceutical treatment options are limited (23). Peripheral immune cells are recruited and activated in the damaged tissue. Those cells can enter the brain parenchyma and release anti-inflammatory cytokines.

Several serious complications often arise after a successful surgical intervention of subarachnoid haemorrhage and aneurysm. One such complication is cerebral vasospasm, occurring in 50 to $70 \%$ of patients (24). These patients suffer from a neurological symptom known as cerebral infarction or Delayed Ischemic Neurological Deficit (DIND). About 30\% of the patients die from this complication. However, effective treatment of vasospasm is limited. The main pathogenic factor of cerebral vasospasm is the reduction of nitrous oxide and activation of the vasoconstrictor (25). Cerebral vasospasm occurs within 3-4 days from the beginning of subarachnoid haemorrhage and reaches its maximum between days 7 and 10 . About $50 \%$ of these patients suffer from severe neurological symptoms such as decrease of consciousness to tongue paresis (26). Delayed complications include recurrent bleeding, brain edema, chronic hydrocephalus and as the most severe - infarction of the brain (27).

\section{Treatment and prognosis}

The treatment of subarachnoid haemorrhage includes early ligation of the aneurysm or insertion of the stent (clip) (28). The conservative postoperative treatment generally involves the prevention of complications, such as cerebral ischaemia. To pre- 
vent vasospasm, different pharmaceutical agents are used such as calcium channel blockers, magnesium sulphate, the statin agent, endothelin antagonists, and the nicardipine implants with extended releaese. However, their effects are limited and there are currently underway various studies about new drugs and treatments (29). The outcome of the disease is influenced by multiple immutable factors and factors that can be influenced by therapeutic interventions and their management. Of great importance in the postoperative recovery is the role of a neurosurgical nurse and physiotherapist with the aim to increase the patients' motor and cognitive functions (30).

\section{Role of neurosurgical nurse in care of neurosurgical patients}

Due to the continuous contact with the patient, the nurse has the responsibility for the basic assessment and ability to recognize the subtle and acute changes in patients with subarachnoid haemorrhage. Nursing care of neurosurgical patients in the early postoperative period is focused on monitoring the patient's condition, eliminating or reducing physical symptoms and early symptom recognition (1).

The work of nurses in a neurosurgical unit includes the following:

- knowledge of the patient's medical history,

- monitoring of certain diagnostic parameters,

- organization of care in the postoperative period,

- monitoring of specific parameters such as color and appearance of the skin,

- monitoring vital signs (blood pressure, pulse, oxygen saturation, temperature - in order to recognize early signs of shock which include tachycardia, filiform pulse, decreased blood pressure, paleness, cold sweaty skin, restlessness),

- monitoring the need to replace the fluids (decreased level of sodium and chloride can cause nausea, drowsiness and coma, and reduced levels of potassium result in confusion),

- observation of the neurological and psychological state of the patient (verbalisation of events and understanding spoken words depending on whether deficits were present before surgery and that part of the brain is functional),
- physiotherapy - the nurse can advise the patient to use the affected limb in daily activities, applying passive exercises ensuring the adequate position, using special aids if such aids are part of the program, and assist the patient to remain mobile. A nurse often gives emotional support when the patient is confronted with the loss of bodily functions (1).

Any sort of change should be documented in the nursing care plan. The changes in the patient care need to be documented as well, and care and support for patients and their family members should be continually provided $(1,31)$

The neurological assessment is done periodically and ranges from 15 minutes to 4 hours, which depends on the clinical state of the patient (1). The nurse should include the patients in the planning and implementation of nursing care, which will also help them gain confidence, ask questions, express their insecurity and fear, all of which contributes to the successful preparation for a surgical intervention (1).

\section{Hypotheses}

Patients with proper postoperative nursing care, monitoring and rehabilitation, with aneurysmal subarachnoid haemorrhage and nonaneurysmal haemorrhage, have fewer complications such as neurological deficits, pressure ulcers or nosocomial infections.

\section{Methods}

Respondents: The sample included patients of both genders with a confirmed diagnosis of subarachnoid haemorrhage (aneurysma cerebri, haemorrhagia subarachnoidalis spontanea), that were operated on at the Department of Neurosurgery, University of Sarajevo Clinical Centre, in the period from 1 January 2013 to 31 December 2014. The research included 142 respondents (patients) at the Department of Neurosurgery. There were $50.7 \%$ of men $(n=72)$, and $49.3 \%$ of women $(n=70)$. The participants in the study were of the average age of 54 years or 45 63.2 years. The study did not include the education and occupation of the participants. 
Criteria for inclusion into the study: Patients with a confirmed diagnosis of subarachnoid haemorrhage, patients operated on during the abovestated period, people older than 18 years.

Criteria for exclusion from the study: Patients who were in the abovestated period diagnosed with the same illness and have not undergone surgery, but underwent conservative or neuroradiological treatment (embolization).

Working methods: The research was a retrospective study. A descriptive analytical study was used to compare the data from the patients medical histories and temperature lists who were operated on at the Department of Surgery, University of Sarajevo Clinical Centre.

For the purposes of research, demographic variables were used (age and gender), then, diagnosis, risk factors, surgical treatment, admission time in intensive care, physical therapy, length of hospital stay, complications, recovery, disease outcome.

Statistical and data processing: For statistical and data analysis we used a software package SPSS for
Windows (version 19.0, SPSS Inc., Chicago, Illinois, USA) and Microsoft Excel (version 11, Microsoft Corporation, Redmond, WA, USA).

Nominal and ordinal variables in the research were analyzed using the $\chi^{2}$ test, and for the lack of the expected frequencies we used the Fisher's exact test (for contingency tables). The relationship between two continuous variables was examined using a linear equation and a scatter diagram, and the strength was evaluated with R2. The level of statistical significance was set at $p=0.05$.

\section{Results}

The average age (median) of the respondents was 54 , that is, between the ages of 45 and 63.2. The youngest subject was 21 and the oldest 90 years old.

Aneurysm is more common in women when compared to men $-65.6 \%$ as opposed to $34.4 \%$. In nonaneurysmal subarachnoid haemorrhage this ratio is

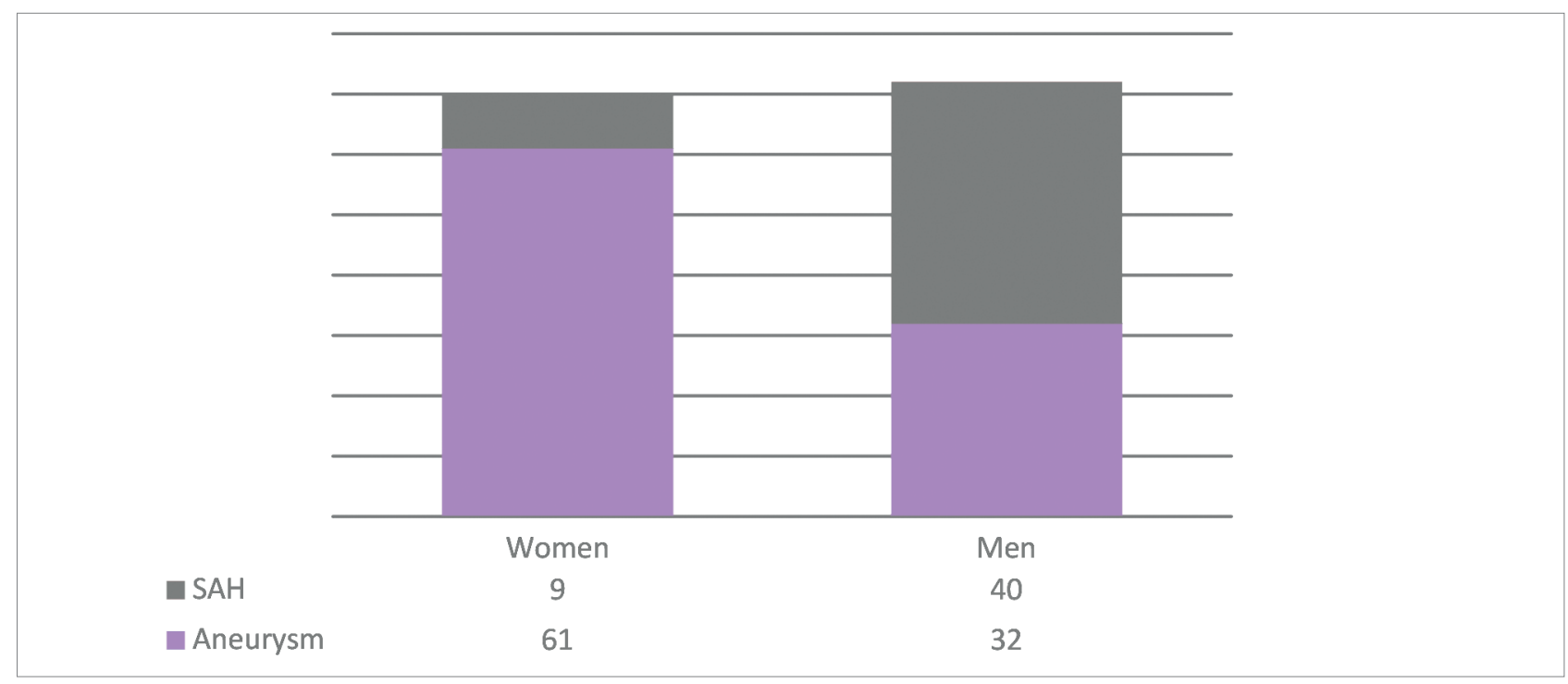

Chart 1 . Gender structure in relation to diagnosis

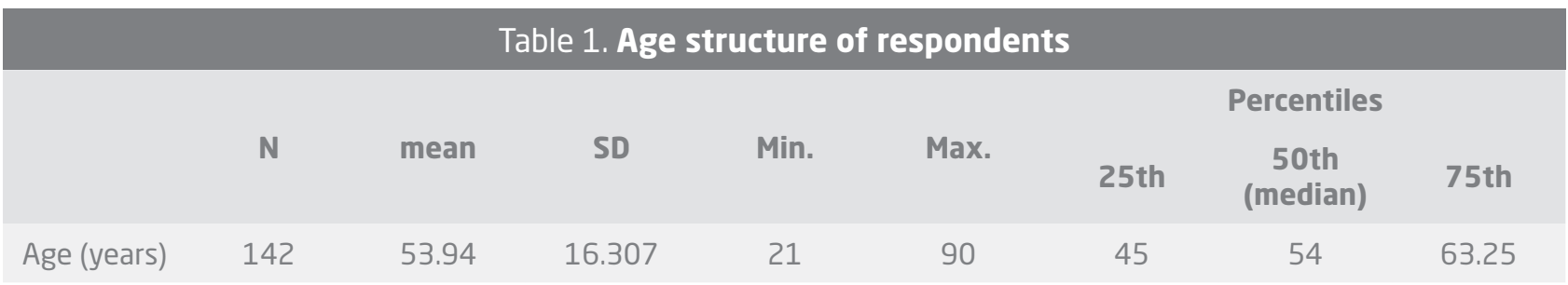


different. Men are represented by $81.6 \%$ and women by $18.4 \%$.

The difference in the ratio of men and women with regards to diagnosis is statistically significant $\chi^{2}=28.6, p=0.0001$.

Respondents with aneurysmal subarachnoid haemorrhage are on average younger - 53 years (45-51), than the patients with nonaneurysmal subarachnoid haemorrhage -61 years (43-78).

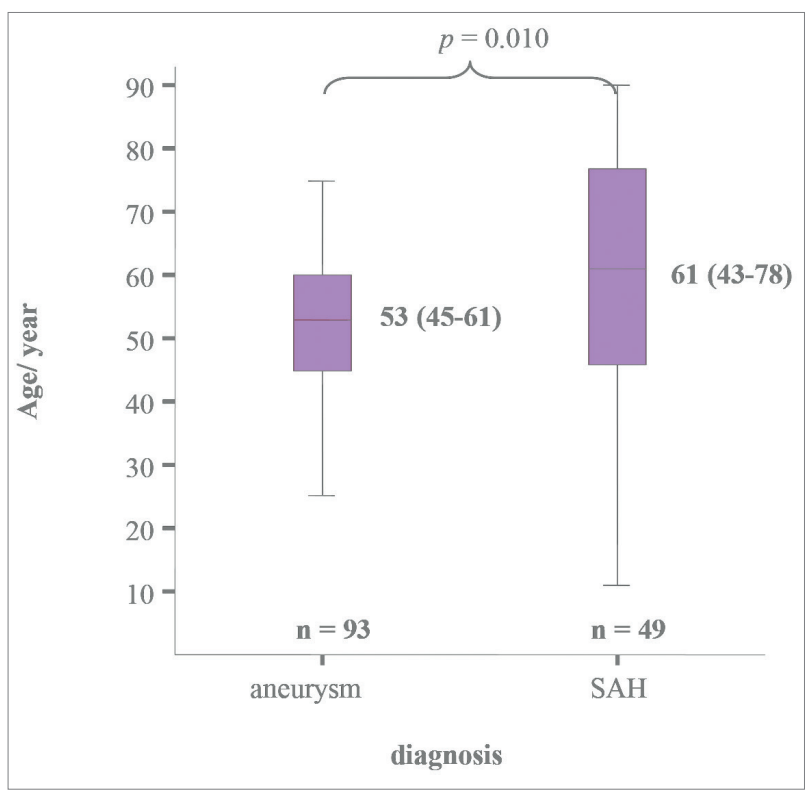

Chart 2. The age structure in relation to the diagnosis/surgery
The percentage of the respondents with preserved consciousness is even at 39\% after the aneurysmal haemorrhage surgery, compared to $36.7 \%$ of the respondents with nonaneurysmal subarachnoid haemorrhage. In the category of the somnolent patients there is a higher percentage of patients with nonaneurysmal subarachnoid haemorrhage $-28.6 \%$, with respect to the $20.4 \%$ of the patients with aneurysmal haemorrhage. The difference is evident in the category of patients with sopor where there is a significantly higher representation of patients after the surgery of subarachnoid haemorrhage $-24.5 \%$, compared to the patients after the aneurysm surgery $-10.8 \%$. The reverse situation can be seen in the category of coma, where there is a much higher number of patients after the operated aneurysmal haemorrhage surgery $-29.0 \%$, compared to the patients after the nonaneurysmal subarachnoid haemorrhage surgery $-10.2 \%$.

After the surgery the verbal response of the respondents was investigated within five categories. In both groups of respondents the highest percentage of respondents were responsive $-37.6 \%$ after the surgery of aneurysmal and $28.6 \%$ after the surgery of nonaneurysmal subarachnoid haemorrhage. There were approximately $14 \%$ of disoriented respondents after aneurysmal surgery and $16.3 \%$ after the surgery of nonaneurysmal subarachnoid haemorrhage. There was a significantly higher percentage of confused patients $(24.5 \%)$ after the surgery of nonaneurysmal subarachnoid haemorrhage than the percentage of patients after aneurismal subarachnoid haemorrhage

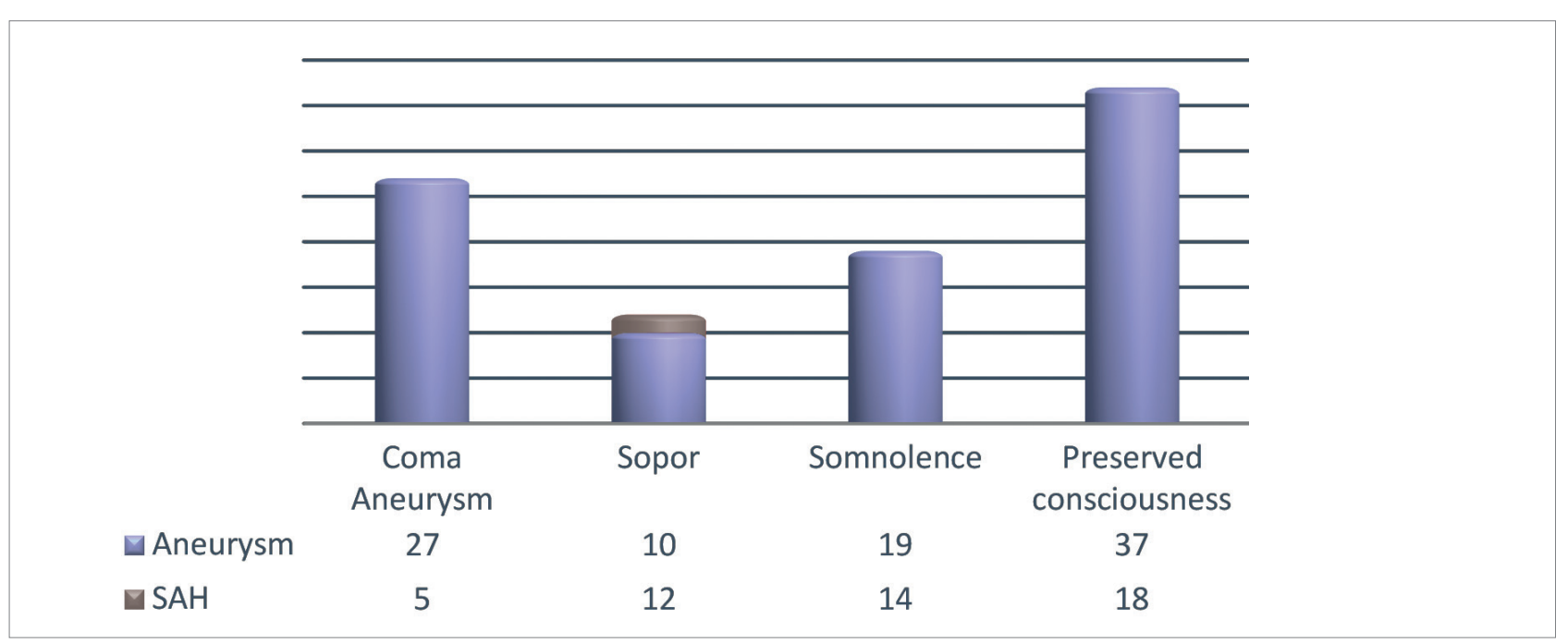

Chart 3. State of consciousness in relation to the diagnosis/surgery 
surgery (16.1\%). Every third respondent (32.3\%) did not answer questions after aneurysmal surgery, while the number is twice as smaller after the surgery of nonaneurysmal subarachnoid haemorrhage (16.3\%). There were no patients with motor dysphasia after aneurysmal surgery while after the surgery of nonaneurysmal subarachnoid haemorrhage that number was significantly higher at $14.3 \%$.

The table shows the share of respondents with different degrees of neurological deficit in relation to the operation. The category of nonaneurysmal subarachnoid haemorrhage is dominated by patients with hemiparesis at $40.8 \%$, followed by patients with nausea at $28.6 \%$, hemiplegia in $14.3 \%$ of the patients, and then patients without any neurological deficit at $10.2 \%$, and only $6 \%$ of the patients which are immobile.

Among respondents after aneurysmal subarachnoid haemorrhage surgery the most common are those with no neurological deficit at $27.5 \%$, then the respondents experiencing weakness at $23.1 \%$, immobile respondents at $20.9 \%$, and respondents with hemiparesis at $17.6 \%$ and hemiplegia at $11 \%$.
Only $2 \%$ of the patients after the aneurysmal subarachnoid haemorrhage surgery were not monitored (continuous monitoring of the vital signs: heart rate, systolic and diastolic pressure, saturation, respiration, temperature and intracranial pressure (ICP), while the share of such patients after the nonaneurysmal subarachnoid haemorrhage surgery was significantly higher $-24.5 \%$.

The average time spent in the hospital is statistically different between these two groups, $p=0.001$. For the respondents with aneurysmal subarachnoid haemorrhage the average hospital stay was 18 (1224) days, as opposed to those with nonaneurysmal subarachnoid haemorrhage where the average length was 9 (7-12) days.

In the group of respondents who were operated on for an aneurysm the values of systolic blood pressure were 120 (110-140) mmHg, whereas in the group of respondents operated on for subarachnoid haemorrhage the systolic blood pressure values were 120 (110-130) mmHg. Values of pressure were even at $p=0.932$. In both groups the average values ranged within the limits of the reference range.

\begin{tabular}{|c|c|c|c|c|c|c|c|c|}
\hline & \multirow{2}{*}{\multicolumn{2}{|c|}{$\begin{array}{l}\text { Responsive } \\
\text { Disoriented }\end{array}$}} & \multicolumn{5}{|c|}{ Verbal response } & \multirow[b]{2}{*}{ Total } \\
\hline & & & Confused & $\begin{array}{l}\text { Does not } \\
\text { answer }\end{array}$ & $\begin{array}{c}\text { Motor } \\
\text { dysphasia }\end{array}$ & & & \\
\hline \multirow{6}{*}{ 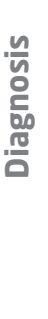 } & \multirow{2}{*}{ Aneurysm } & $\mathrm{N}$ & 35 & 13 & 15 & 30 & 0 & 93 \\
\hline & & $\%$ & 37.6 & 14 & 16.1 & 32.3 & 0 & 100 \\
\hline & \multirow{2}{*}{ SAH } & $N$ & 14 & 8 & 12 & 8 & 7 & 49 \\
\hline & & $\%$ & 28.6 & 16.3 & 24.5 & 16.3 & 14.3 & 100 \\
\hline & \multirow{2}{*}{$\begin{array}{c}\text { Total } \\
\%\end{array}$} & $N$ & 49 & 21 & 27 & 38 & 7 & 142 \\
\hline & & 34.5 & 14.8 & 19 & 26.8 & 4.9 & 100 & \\
\hline
\end{tabular}

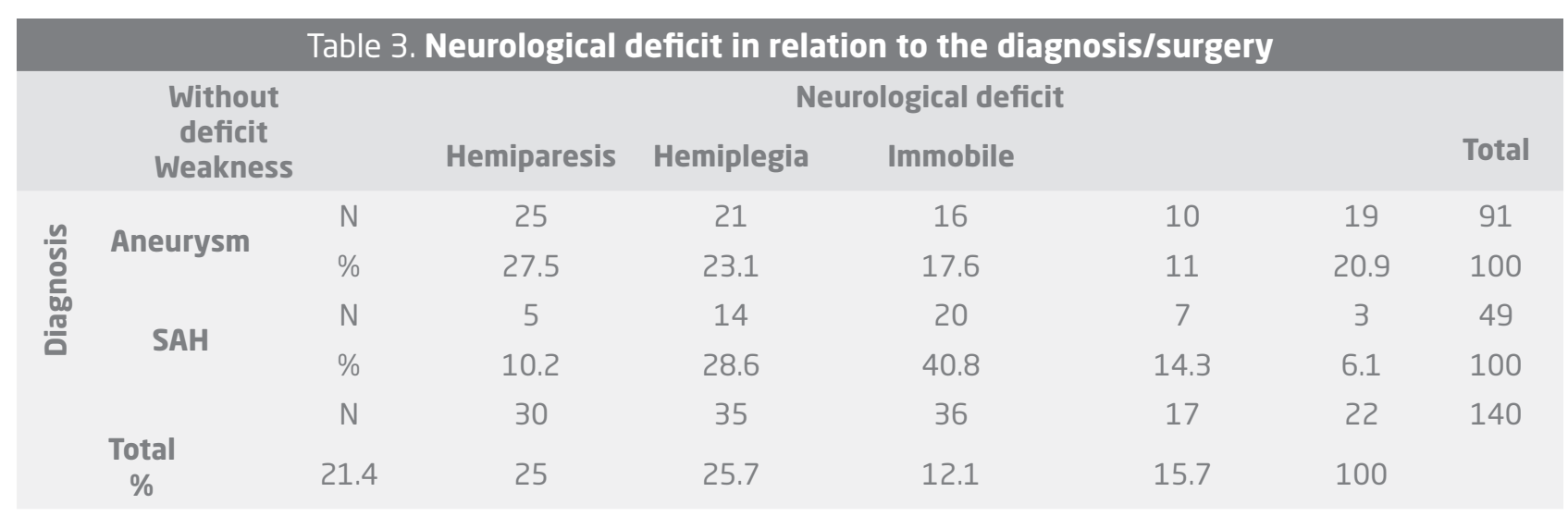




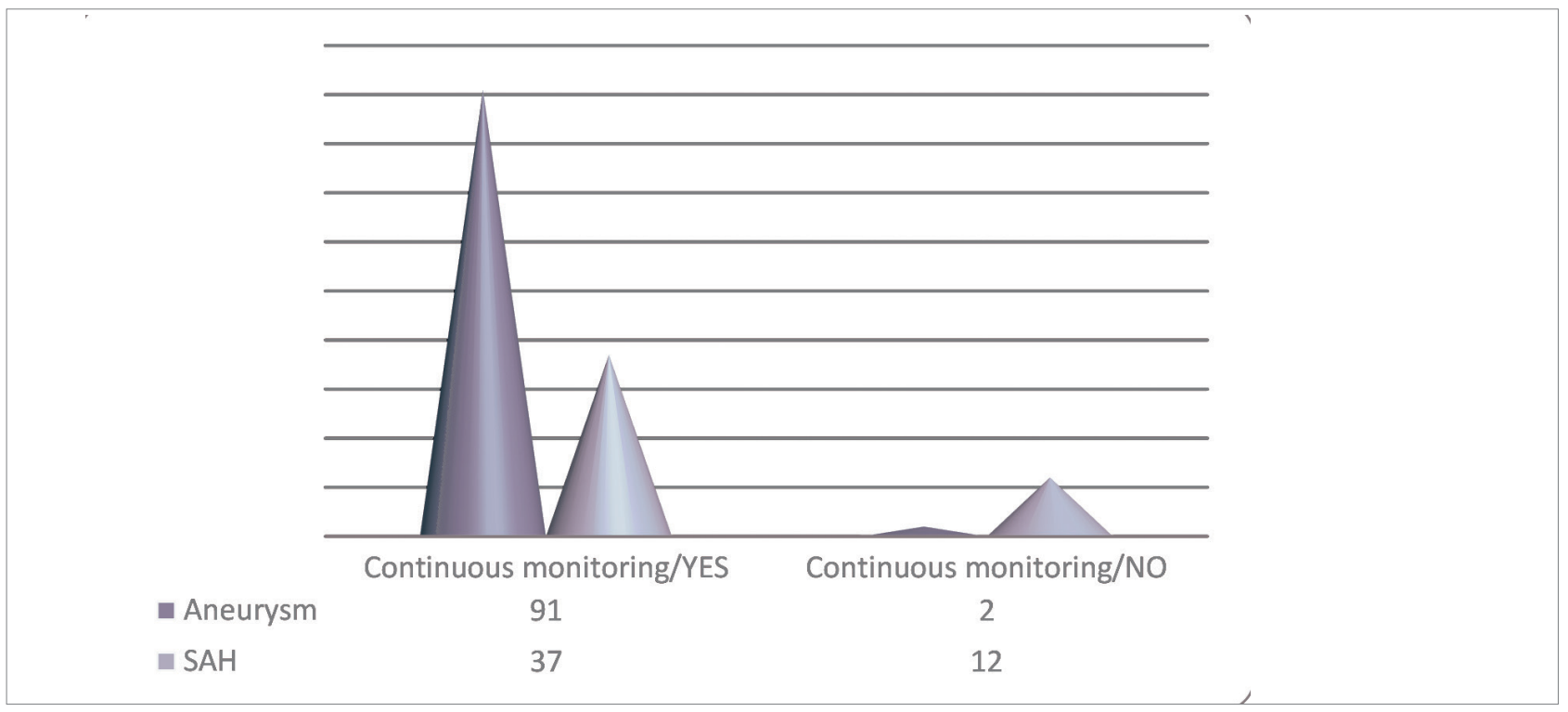

Chart 4. Monitoring of patients after the aneurysmal and nonaneurysmal subarachnoid haemorrhage surgery

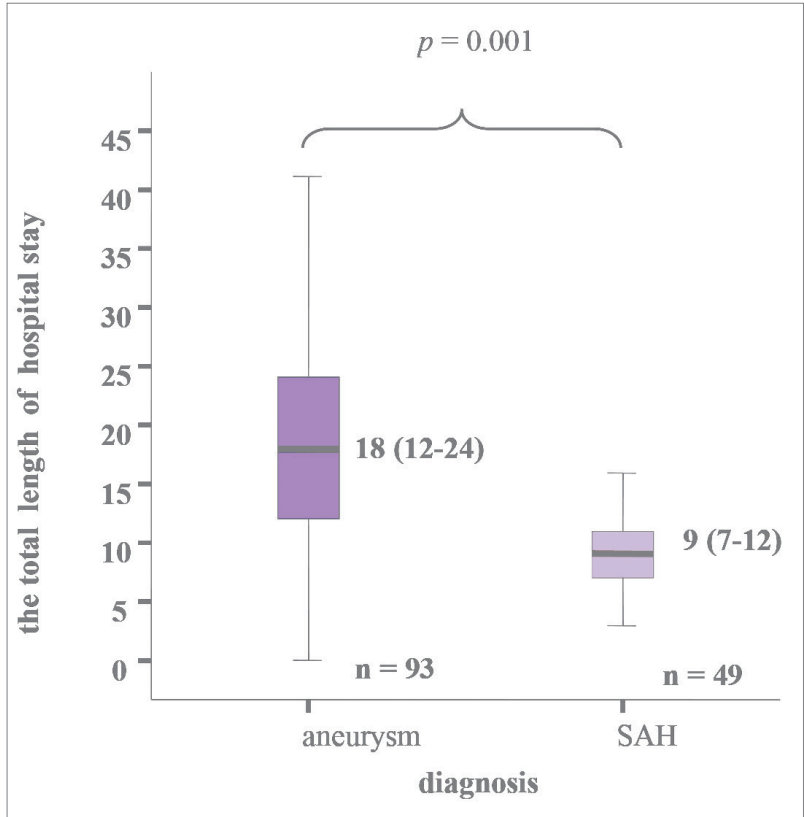

Chart 5. Length of hospital stay after aneurysmal and nonaneurysmal subarachnoid haemorrhage surgery

In the group of respondents who were operated on for aneurysmal subarachnoid haemorrhage the values of diastolic blood pressure were $70(60-80)$ $\mathrm{mmHg}$, while in the group of respondents operated on for nonaneurysmal subarachnoid haemorrhage the values of pressure diastolic were $70(60-80)$

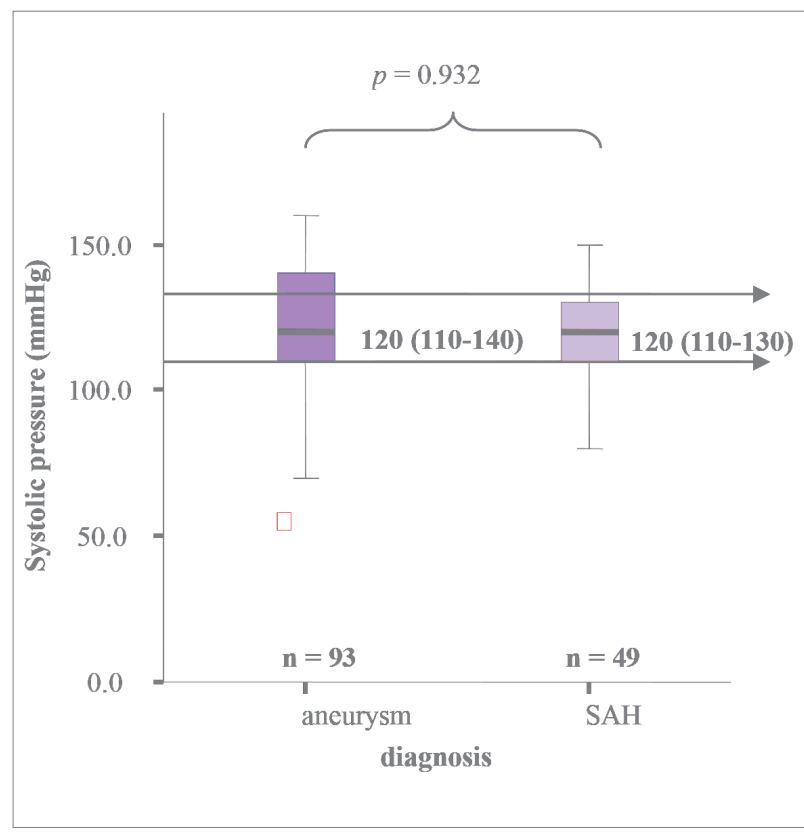

Chart 6. The average values of systolic pressure after the subarachnoid haemorrhage surgery

$\mathrm{mmHg}$. Values of pressure were even at $p=0.619$. In both groups the average values ranged within the limits of the reference range.

In the group of respondents operated on for an aneurysm the average number of respiration per minute amounted to 18 (16-19), while in the group of patients 


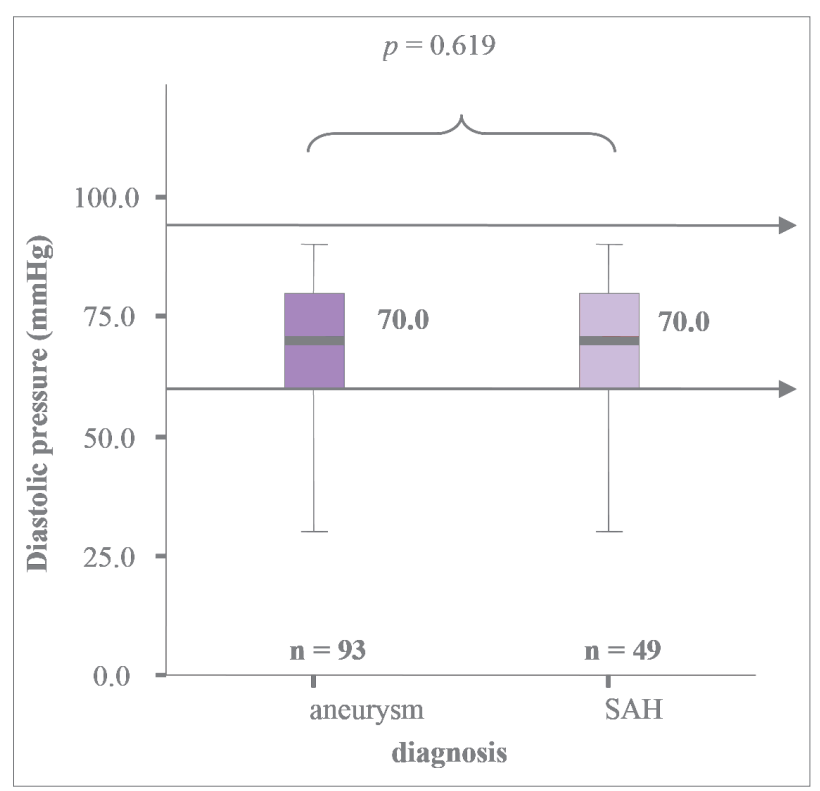

Chart 7. The average values of diastolic pressure after the subarachnoid haemorrhage surgery

operated on for subarachnoid haemorrhage the average respiratory rate was $18(18-20) \mathrm{mmHg}$. In both groups the average values of respiration per minute were within the limits of the reference range (12-20).

In respondents that were treated surgically for an aneurysm the average value of pulse was 79 (74-90)/

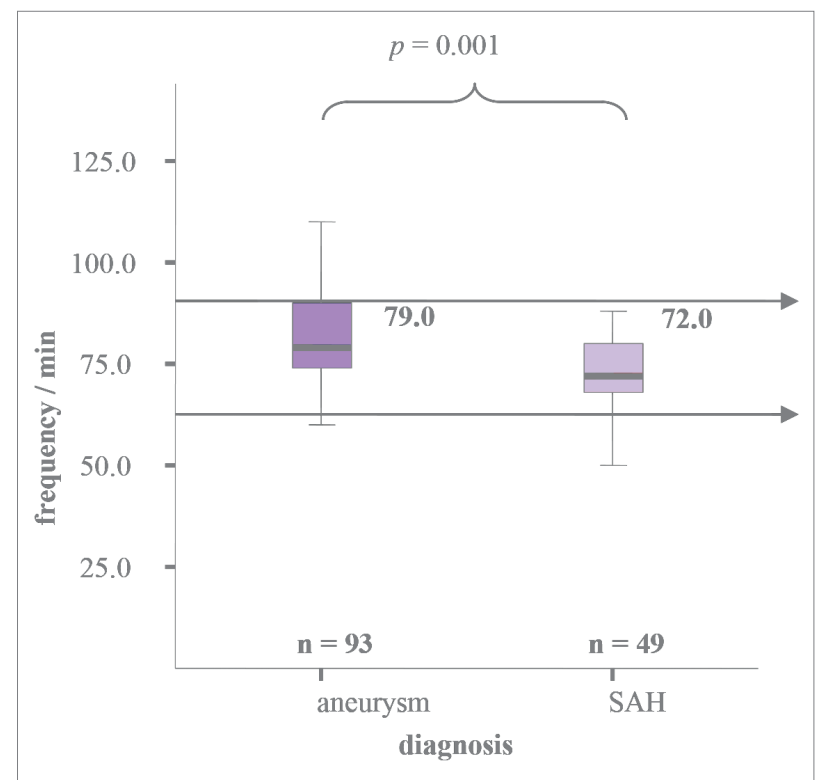

Chart 9. The average values of pulse after aneurysmal and nonaneurysmal subarachnoid haemorrhage surgery

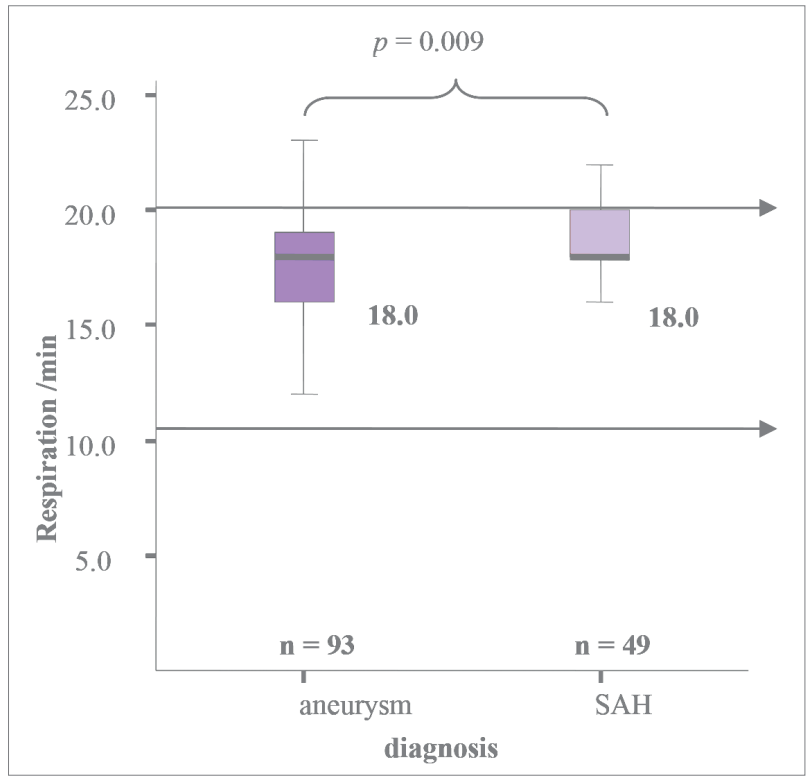

Chart 8. The average values of respiration after aneurysmal and nonaneurysmal subarachnoid haemorrhage surgery

min, while in the group of respondents treated surgically for subarachnoid haemorrhage this average was lower, at $72(68-80) / \mathrm{min}$. In the respondents treated for an aneurysm there was on average a higher pulse frequency.

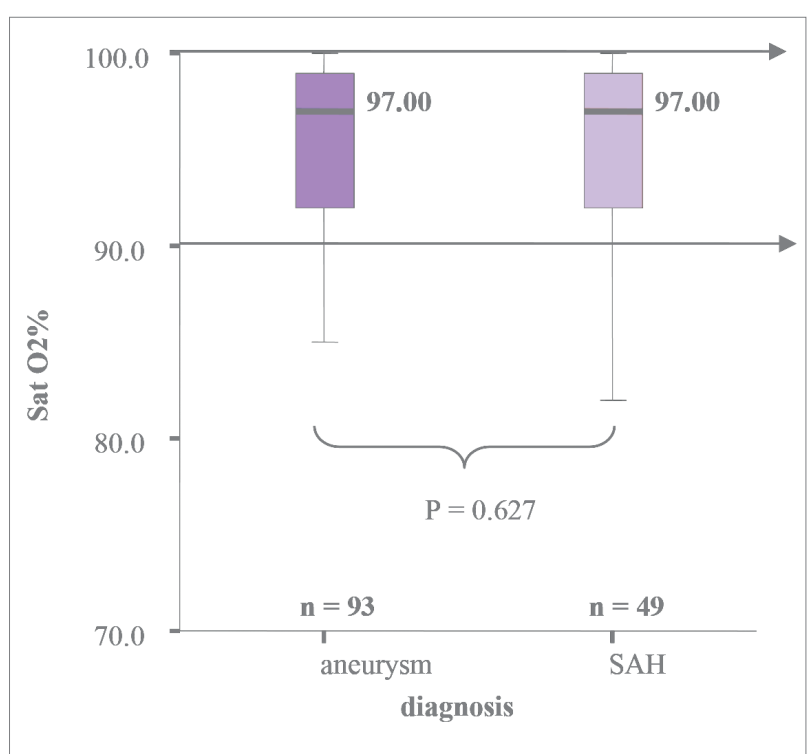

Chart 10. The average values of oxygen saturation

of the participants after aneurysmal and nonaneurysmal subarachnoid haemorrhage surgery 
In respondents treated surgically for an aneurysm the average oxygen saturation was 97 (92-99)\%, while in the group of respondents treated surgically for subarachnoid haemorrhage the average saturation was 97 (91-99)\%. The average values of oxygen saturation between the two groups of respondents were even, $p=0.627$ respectively, and there was no significant statistical difference. In both groups of the respondents the saturation values were inside the reference interval of $90-100 \%$.
Of the total sample in the group with aneurysmal subarachnoid haemorrhage, 9 of the respondents $(9.7 \%)$ acquired ventilator-associated pneumonia and $2(4.1 \%)$ in the group with nonaneurysmal subarachnoid haemorrhage.

There was incidence of nosocomial infections in 16 patients with aneurysmal subarachnoid haemorrhage $(17.2 \%)$. There was a similar situation in those patients operated on due to nonaneurysmal

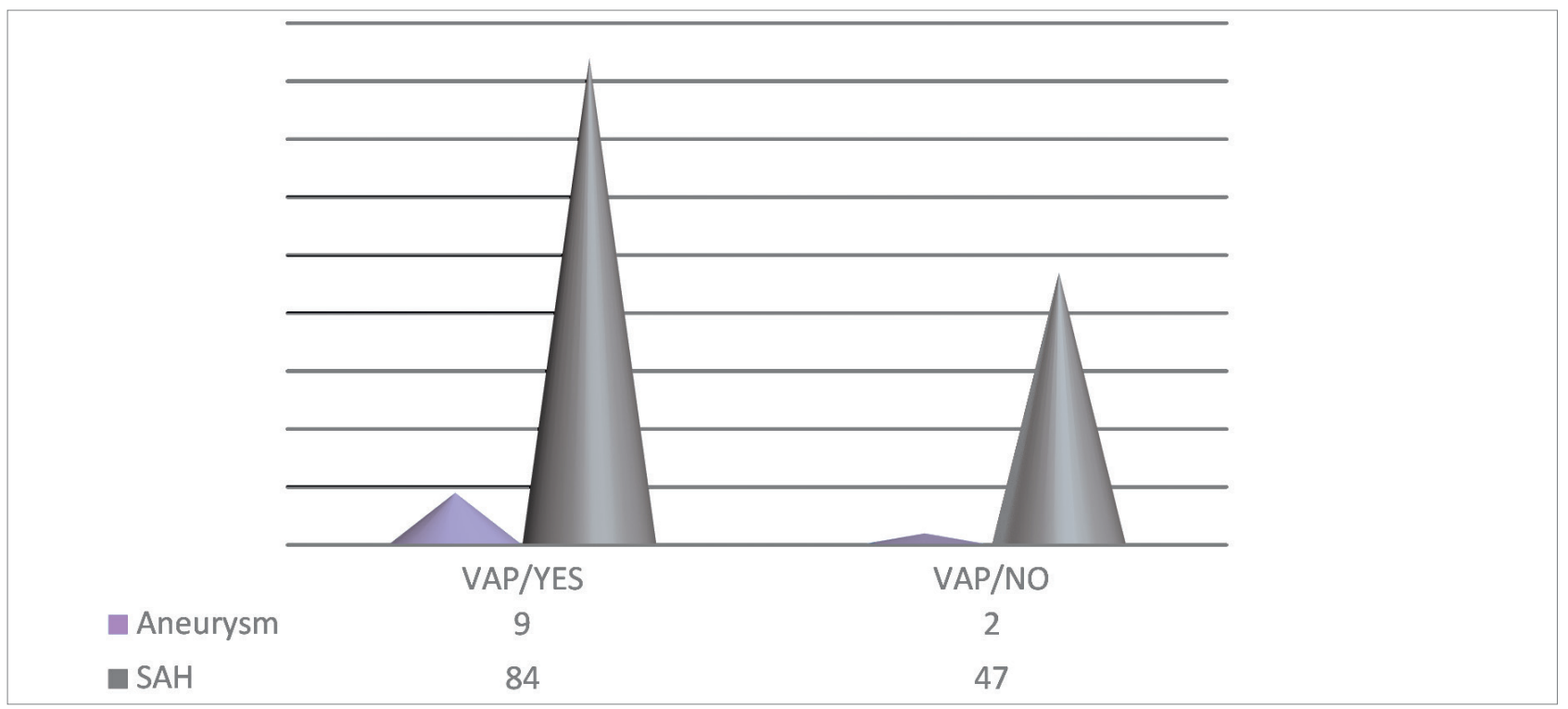

Chart 11. Ventilator-associated pneumonia as a complication after aneurysmal and nonaneurysmal subarachnoid haemorrhage surgery

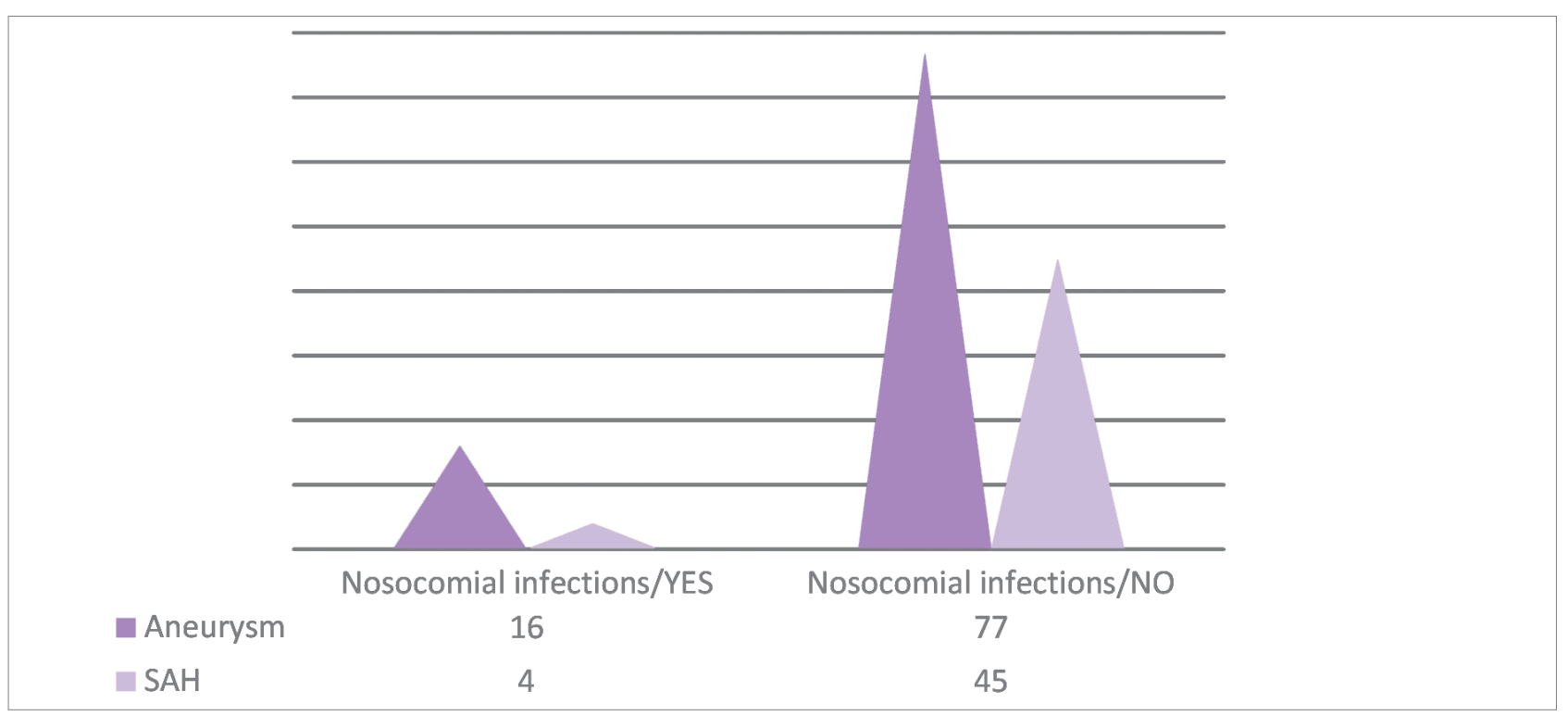

Chart 12. Nosocomial infections as a complication after aneurysmal and nonaneurysmal subarachnoid haemorrhage surgery 
subarachnoid haemorrhage -4 (8.2\%) of them had nosocomial infections. No statistical difference was noted.

Fatal outcome was observed in a total of 30 (32.6\%) patients operated on for an aneurysm, and around one third of the patients - 62 (67.4\%), survived after the surgery. The number of respondents with a fatal outcome who underwent surgery for subarachnoid haemorrhage was smaller than in the patients with aneurysmal haemorrhage $4(8.2 \%)$, while there were $45(91.8 \%)$ of the respondents who survived. The number of patients with the fatal outcome was statistically different between the two diseases $\chi^{2}=11.8 p=0.001$.

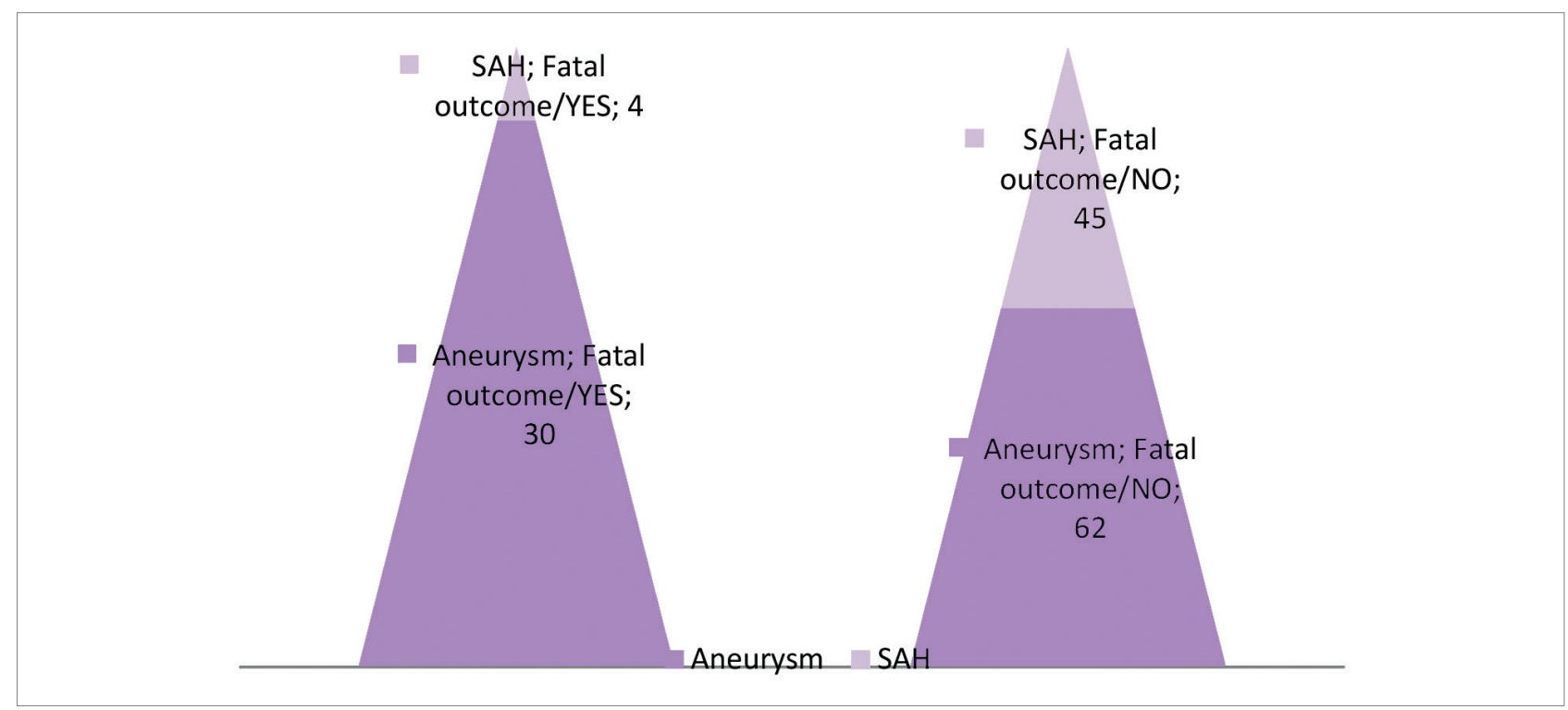

Chart 13. The number of respondents with a fatal outcome with respect to aneurysmal and nonaneurysmal subarachnoid haemorrhage

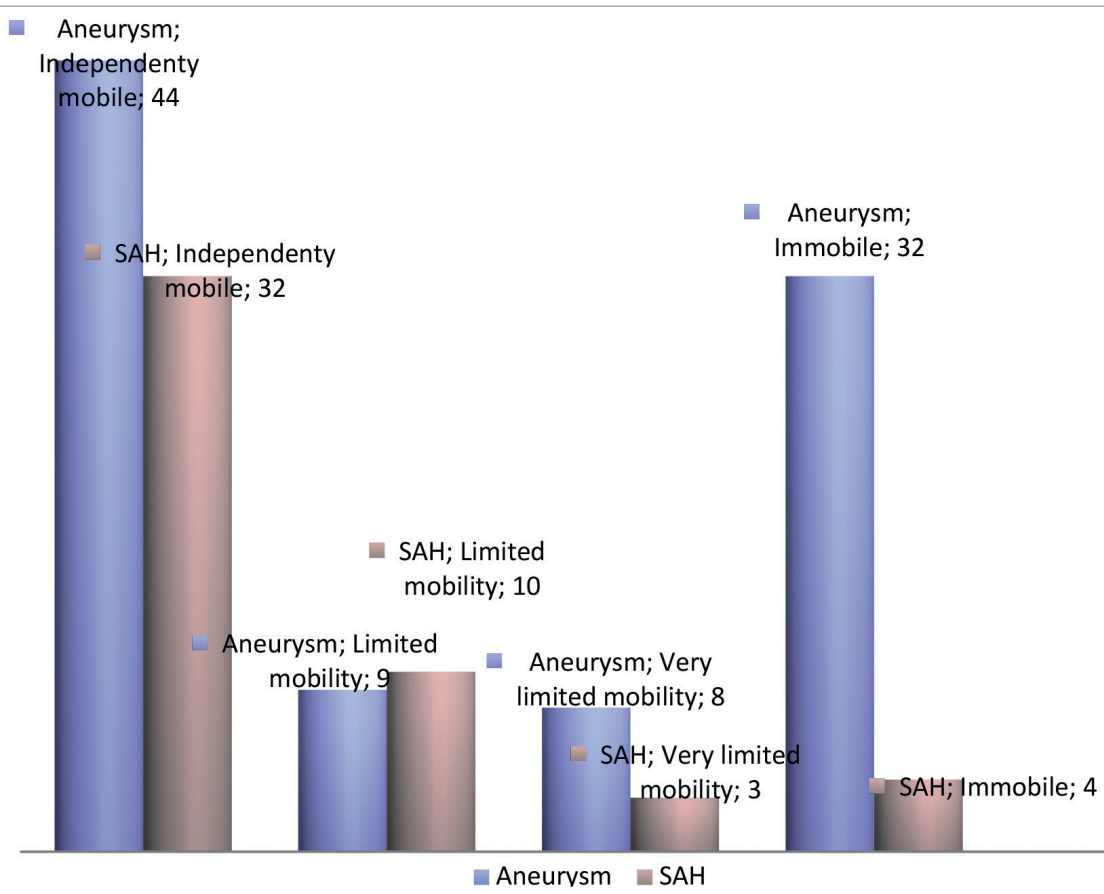

Chart 14. The mobility of patients after surgery 
Of the total number of patients operated on for an aneurysm, 44 (47.3\%) was independently mobile after surgery, $9(9.7 \%)$ had limited mobility, 8 (8.6\%) had very limited mobility and 32 (34.4\%) were immobile. Most of the respondents operated on for subarachnoid haemorrhage were either independently mobile after the operation - 32 (65.3\%), 10 (20.4\%) had limited mobility, $3(6.1 \%)$ had very limited mobility and only four (8.2\%) were immobile. The mobility of patients after surgery was statistically significant $-\chi^{2}=15.244, p=0.002$.

There was a fatal outcome for $30(32.6 \%)$ patients operated on for an aneurysm, two thirds of them survived after surgery - 62 (67.4\%), 11 respondents had a middle level of physical ability (11.8\%), 5 had poor physical ability (5.4\%), and only 2 (2.2\%) respondents had very low level of physical ability after surgery. More than half of the respondents were in a good physical state after surgery. The physical state of the group treated for nonaneurysmal subarachnoid haemorrhage did not improve in 5 (10.2\%) respondents, middle level of physical ability was observed in $9(18.4 \%)$ respondents, and there was only one respondent (2\%) who had a poor level of physical ability after surgery. More than half of the respondents were in a good physical state after surgery.

\section{Discussion}

Research was conducted at the Department of Neurosurgery, University of Sarajevo Clinical Centre on a sample of 142 patients. The topic of the study was related to the testing of the monitoring in the treatment of surgical patients with aneurysmal and nonaneurysmal subarachnoid haemorrhage in terms of nursing care.

Both genders in the research were evenly represented which is evident in other research of the same nature (32). However, different studies had different prevalence. Schertz and colleagues presented results that showed the increased risk of subarachnoid haemorrhage with female participants, and that the risk increased with age. In the Konczalla and colleagues research there were more male participants in the sample (33).

The results of our study showed that of the 142 respondents, $65.5 \%$ were hospitalized for aneurysmal subarachnoid haemorrhage surgery, while only $34.5 \%$ were operated on due to nonaneurysmal haemorrhage. Shertz and colleagues showed that during seven years of research the number of subarachnoid haemorrhages was also low (20.7\%). Similar results were found in other research that were dealing with the issue of subarachnoid haemorrhage and aneurysm (Flaherty and colleagues) (36).

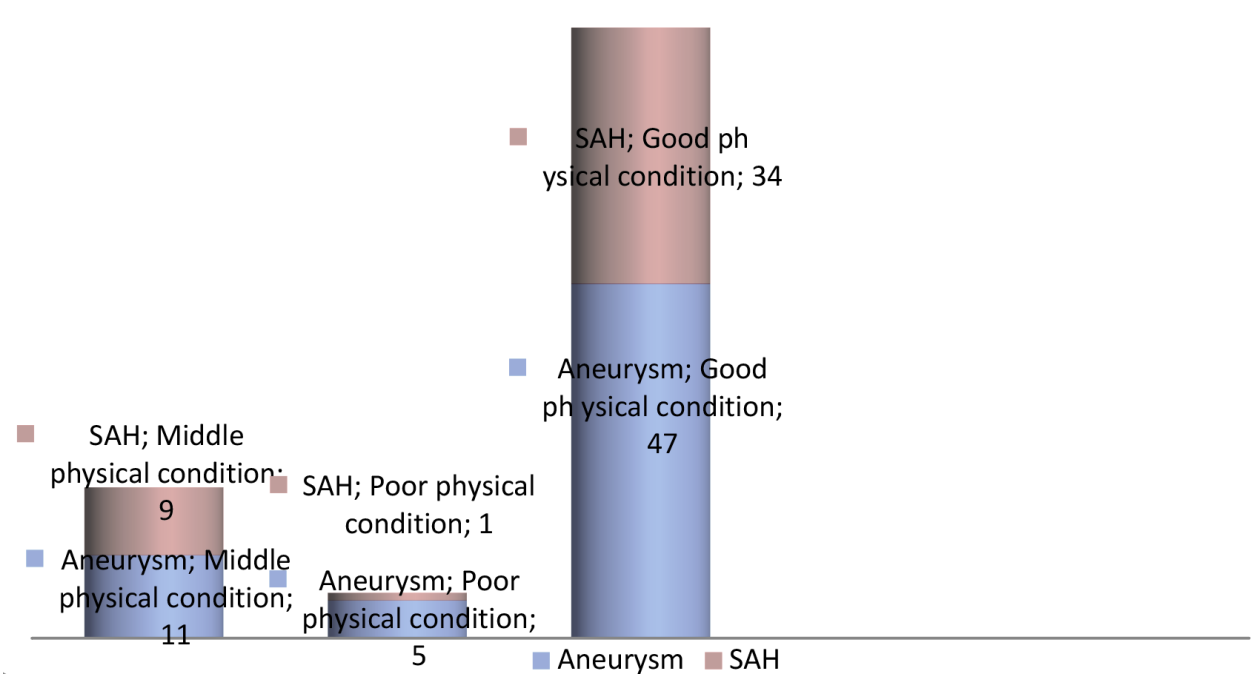

Chart 15. The physical status of patients after surgery 
According to Rooij and colleagues and Schertz and colleagues, women are at a higher risk of subarachnoid haemorrhage and intracranial aneurysms. The results of our research are similar to the abovementioned research, but only for an aneurysm where female participants dominate in the ratio of $65.6 \%$ to $34.4 \%$.

However, for the development of subarachnoid haemorrhage, the situation is somewhat different, men are represented in higher numbers than women $-81.6 \%$ to $18.4 \%$. These results can be explained by women's greater concern for their health who at the smallest "signal" that suggests a health problem seek to resolve it (35).

According to research by Alg and associates, subarachnoid haemorrhage is more often in women than in men (2:1), with a peak incidence in people between 50 and 60 years of age. In our research subarachnoid haemorrhage was more present in men than in women with the ratio of $81.6 \%$ to $18.4 \%$.

In both genders, the average age of subarachnoid haemorrhage morbidity corresponds to other studies, on average 61 years of age (33).

However, there was a significant difference in the category of those with an aneurysm, which in both gender categories were younger - 53 years of age (36). The explanation lies in the potential danger of an unruptured aneurysm that is often discovered by accident in younger population.

The fundamentals of monitoring the patients after the surgery of subarachnoid haemorrhage include the use of the advanced technologies for monitoring the patients with injuries to the brain. Recommended interventions include placing the ventricular catheter, prophylaxis against recurrent bleeding and control of intracranial pressure and optimization of central venous pressure. In a sense there is a need to provide an optimal physiological environment that will help the promotion of normal neuron recovery (37).

Our research was limited in terms of the monitoring the vital parameters via ECG monitor (heart rate, systolic and diastolic pressure, oxygen saturation, temperature, respiration), that is, those parameters that nurses in the intensive care unit are in charge of. The results showed that only $2 \%$ of the patients after aneurysm surgery are not on continuous non-invasive monitoring (apparatus for monitoring vital parameters), while the share of patients after subarachnoid haemorrhage surgery was significantly higher at $24.5 \%$.
However, the high rate of monitoring is present in both categories, regardless of the higher percentage of those who had a good postoperative recovery in both categories. These results support the conscientious monitoring of the patient by the medical staff. In the intensive care unit, where there is already a high number of patients in a serious health condition, postoperative monitoring is continuous (38).

In our study, there was a statistical difference between the average hospital stay of the patients with aneurysmal and patients with nonaneurysmal subarachnoid haemorrhage. The respondents with an aneurysm on average stayed 18 days (12-24) in hospital, as opposed to those with nonaneurysmal subarachnoid haemorrhage, where the average stay was 9 days (7-12). The explanation is logical considering that a higher percentage of patients with aneurysmal subarachnoid haemorrhage (34.4\%) were immobile after surgery, as opposed to those who suffered from nonaneurysmal subarachnoid haemorrhage $(8.2 \%)$ and demanded additional treatment. As shown by Frontera and colleagues, the average hospital stay was 8 days (range from 0 to 50 ) but unlike in our study, the length of stay was increased in relation to infection. All infections that were considered, led to the prolongation of hospitalization (39).

For the assessment of the current state of the volume and the condition of bloodstream, many parameters must be taken into account and interpreted together, taking into consideration the condition of the patient. Therefore, this interpretation remains very hard to do. The average values of systolic and diastolic blood pressure were inside the reference values, $120 \mathrm{mmHg}$ systolic and $70 \mathrm{mmHg}$ diastolic pressure, unified for both categories of respondents of the study - both for those with aneurysmal and those with nonaneurysmal subarachnoid haemorrhage.

The known risk factors for subarachnoid haemorrhage are smoking, hypertension and excessive alcohol intake. Smoking and hypertension are seen to have an addictive effect. A study by Vlak and colleagues did not characterize hypertension as a risk factor for subarachnoid haemorrhage and aneurysm. They noted smoking as one of the possible risk factors. Also, smoking, drinking and hypertension, as factors that can be modified in general population, can be used as a means to reduce this pathology. Unfortunately, our study is retrospective, so we were not in a position to analyze these individual factors $(40,41)$. 
Although a history of hypertension does not increase the risk of rupture, however, a sharp rise in blood pressure can be the cause of aneurysmal rupture (42).

The results of the studies of Morita and colleagues, as well as Vlak and colleagues, did not find significant connections between hypertension and aneurysm formation and subarachnoid haemorrhage, only that a sudden and short increase in blood pressure causes subarachnoid haemorrhage. In our study, the test sample was normotensive. However, there were limitations to the study because only the monitoring after the surgical treatment was observed, so there is no insight into what kind of etiological factor caused the condition of aneurysm or subarachnoid haemorrhage. However, indicators support a good monitoring of patients considering the blood pressure postoperatively.

Possible explanation for this finding is that hypertension leads to the formation of aneurysm, but the treatment of hypertension reduces further growth of the aneurysm and thus the risk of subarachnoid haemorrhage (43).

According to a study by Konczalla and colleagues, $85 \%$ of the patients with nonaneurysmal subarachnoid haemorrhage were in good clinical state. Similar results have been shown by other authors. According to our study, more than half of the patients in both categories - with nonaneurysmal and aneurysmal subarachnoid haemorrhage, were of a good physical status, therefore, the results cannot be compared to other studies. In the other half of the respondents, for $30.1 \%$ of them with aneurysmal etiology, the physical state has not improved after surgery, while that percentage is lower in patients with nonaneurysmal subarachnoid haemorrhage $-10.2 \%$. Since patients were treated in only one clinic, and were equally under the control of doctors and nurses, this clinical course can be attributed to the severity, that is, to the aneurysm as a cause of subarachnoid haemorrhage which as such has a more severe clinical course.

The neurological status of the analyzed sample was such that $57 \%$ of those with aneurysmal subarachnoid haemorrhage were conscious and communicative. A significantly higher percentage, $75.5 \%$ of them, were in the category of nonaneurysmal subarachnoid haemorrhage. Contrary to this good neurological outcome, $31.2 \%$ of the respondents with aneurysms were in a coma after surgery, while in the category of nonaneurysmal haemorrhage, only $8.2 \%$ of the respondents were in a coma.
Konczalla and colleagues had a better neurological outcome in $83 \%$ of the patients with nonaneurysmal subarachnoid haemorrhage (45).

\section{Conclusion}

- Of the 142 respondents in the sample, 65.5\% were hospitalized for aneurysmal subarachnoid haemorrhage surgery, and $34.5 \%$ of the patients were operated on for nonaneurysmal subarachnoid haemorrhage. The average age of the respondents was 54 years, there was equal gender structure with a slight predominance of men (57\%). Aneurysmal subarachnoid haemorrhage was more frequent among women (65.6\%). Respondents with nonaneurysmal subarachnoid haemorrhage were older - 61 (43-62) years of age.

- Only $2 \%$ of the patients after aneurysmal subarachnoid haemorrhage surgery were monitored, while the number of the monitored patients after nonaneurysmal subarachnoid haemorrhage surgery was significantly higher at $24.5 \%$.

- Fatal outcome was present in a total of 30 (32.6\%) patients operated on for aneurysmal subarachnoid haemorrhage, while the percentage of those who were operated on due to nonaneurysmal haemorrhage was lower and amounted to 4 (8.2\%). Surviving patients, those with aneurysmal subarachnoid haemorrhage, on average stayed in hospital for 18 (12-24) days.

- The tasks of nurses in the process of nursing care of neurosurgical patients are related to the monitoring of vital parameters, monitoring the status of the skin and development of pressure ulcers, states of consciousness according to the Glasgow coma scale, and initiation of physical therapy.

- The indicators of quality of nursing care (ventilator-associated pneumonia, nosocomial infections, bedsores) between the two categories of patients who were operated on due to aneurysmal and nonaneurysmal subarachnoid haemorrhage, did not show statistical difference. 
- Based on the results of the research, the arguments were obtained to confirm the working hypothesis of the research that a large number of complications in surgical patients after aneurysmal and nonaneurysmal subarachnoid haemorrhage can be prevented with proper nursing care, monitoring and rehabilitation.

\section{References}

1. Kurtović B. Zdravstvena njega neurokirurških bolesnika. Zagreb: Hrvatska komora medicinskih sestara; 2013. Croatian.

2. Schertz M, Mehdaoui H, Hamlat A, Piotin M, Banydeen $\mathrm{R}$, Mejdoubi M. Incidence and Mortality of Spontaneous Subarachnoid Haemorrhage in Martinique. PLoS One. 2016;11(5):e0155945.

3. Lange F. Nursing management of subarachnoid haemorrhage: A reflective case study. BJNN. 2009;5(10):463-70.

4. Rotim K, Sajko T. Neurokirurgija. Zagreb: Zdravstveno veleučilište; 2010. Croatian.

5. Mauk K. Rehabilitation Nursing: A Contemporary Approach to Practice. Massachusetts: Jones \& Bartlett Learning; 2011.

6. Ashley M. Traumatic Brain Injury: Rehabilitation, Treatment and Case Management. 3rd ed. New York: CRC Press; 2010.

7. Steiner $T$, juvela $S$, Jung $F$, Forsting $M$, Rinkel G. European Stroke Organization Guidelines for the Management of Intracranial Aneurysms and Subarachnoid Haemorrhage. Cerebrovasc Dis. 2013;35(2):93-112.

8. Rahman M, Smietana J, Hauck E, Hoh B, Hopkins N, Siddiqui $A$, et al. Size ratio correlates with intracranial aneurysm rupture status: a prospective study. Stroke. 2010;41(5):916-20.

9. Zhao L, Zhang L, Zhang X, Li Z, Tian L, Wang YX. An analysis of 1256 cases of sporadic ruptured cerebral aneurysm in a single Chinese institution. PLoS One. 2014;9(1):e85668.

10. Wermer MJ, van der Schaaf IC, Algra A, Rinkel G]. Risk of rupture of unruptured intracranial aneurysms in relation to patient and aneurysm characteristics: an updated meta-analysis. Stroke. 2007;38(4):1404-10.

11. Vlak MH, Rinkel GJ, Greebe P, Algra A. Independent Risk Factors for Intracranial Aneurysms and Their Joint Effect: A Case-Control Study. Stroke. 2013;44(4):984-7.

12. Higashida R, Alberts MJ, Alexander DN, Crocco TJ et al. Interactions Within Stroke Systems of Care. A Policy Statement From the American Heart Association/American Stroke Association. Stroke. 2013;44(10):2961-84.
13. Hickey JV. The Clinical Practice of Neurological and Neurosurgical Nursing. 6th ed. Philadelphia: Wolters Kluwer Health/Lippincott Williams \& Wilkins; 2009.

14. Morita A, Kirino T, Hashi K, Aoki N, Fukuhara S, Hashimoto et al. The natural course of unruptured cerebral aneurysms in a Japanese cohort. $N$ Engl J Med. 2012;366(26):2474-82.

15. de Rooij NK, Linn FH, van der Plas I, Algra A, Rink $G$ ]. The incidence of subarachnoid haemorrhage: a systematic review with emphasis on region, age, gender and time trends. J Neurol Neurosurg Psychiatry. 2007;78(12):1365-72.

16. McCarron M, Okane MJ. Accurate diagnosis of subarachnoid haemorrhage. Ann Clin Biochem. 2014;51(6):629-30.

17. Perry JJ, Stiell IG, Sivilotti ML, Bullard MJ, Emond $M$, Symington C, et al. Sensitivity of computed tomography performed within six hours of onset of headache for diagnosis of subarachnoid haemorrhage: prospective cohort study. BMJ. 2011;343:d4277.

18. Naidech AM. Intracranial Haemorrhage. Am J Respir Crit Care Med. 2011;184(9):998-1006.

19. Yu DW, Jung YJ, Choi BY, Chang CH. Subarachnoid haemorrhage with negative baseline digital subtraction angiography: is repeat digital subtraction angiography necessary? J Cerebrovasc Endovasc Neurosurg. 2012;14(3):210-5.

20. Kalauz S. Nastavni tekstovi: Zdravstvena njega kirurških bolesnika. Zagreb: Zdravstveno Veleučilište; 2008. Croatian.

21. Williams LN, Brown RD. Management of unruptured cerebral aneurysms. Neurol Clin Pract. 2013;3(2):99-108.

22. Donnan GA, Hankey G], Davis SM. Intracerebral haemorrhage: a need for more data and new research directions. Lancet Neurol. 2010;9(2):133-4.

23. Bederson JB, Connolly ES Jr, Batjer HH, Dacey RG, Dion, Diringer MN, et al. Guidelines for the management of aneurysmal subarachnoid haemorrhage: A statement for healthcare professionals from a special writing group of the Stroke Council, American Heart Association. Stroke. 2009;40(3):994-1025.

24. Helyar V, Soderman M, Andersson T, Holmin S. Vertebrobasilar dissection with pseudo-aneurysm or subarachnoid haemorrhage: Intracranial Stenting as the Only Treatment. A Report of Three Cases. Interv Neuroradiol. 2009;15(1):87-91.

25. Kelliny M, Maeder P, Binaghi S, Levivier M, Regli L, Meuli R. Cerebral aneurysm exclusion by CT angiography based on subarachnoid haemorrhage pattern: a retrospective study. BMC Neurol. 2011;11:8.

26. Van der Jagt M. Fluid management of the neurological patient: a concise review. Crit Care. 2016;20(1):126.

27. Cruickshank A, Auld P, Beetham R, Burrows G, Egner W, Holbrook I, et al. Revised national guidelines for analysis of cerebrospinal fluid for bilirubin and suspected subarachnoid haemorrhage. Ann Clin Biochem. 2008;45(3):238-44. 
28. Pyysalo LM, Niskakangas TT, Keski-Nisula LH, Kahara VJ, Ohman JE. Long term outcome after subarachnoid haemorrhage of unknown aetiology. J Neurol Neurosurg Psychiatry. 2011;82(11):1264-6.

29. Alam S, Wakil Udin AN, Mojumder MR, Hossain K, Tarikul KM, Farhana S, et al. Intracranial Aneurysms: Acute VS delayed Surgery An Analysis of 52 Cases. Bangladesh Crit Care J. 2013;1:33-9.

30. Kang H, Ji W, Qian Z, Li Y, Jiang C, Wu Z, et al. Aneurysm Characteristics Associated with the Rupture Risk of Intracranial Aneurysms: A Self-Controlled Study. PLoS One. 2015;10(11):e0142330.

31. Veerbeek JM, van Wegen $E$, van Peppen $R$, van der Wees PJ, Hendriks E, Rietberg M, et al. What Is the Evidence for Physical Therapy Poststroke? A Systematic Review and Meta-Analysis. PLoS One. 2014;9(2):e87987.

32. Diepenbrock N. Quick Reference to Critical Care. 3rd ed. Philadelphia: Lippincott Williams \& Wilkins; 2008.

33. Ajiboye N, Chalouhi N, Starke RM, Zanaty M, Bell R. Unruptured Cerebral Aneurysms: Evaluation and Management. Scientific World Journal. 2015;2015:954954.

34. Zhong $W$, Zhao $P$, Wang $D$, Li G, Sun $H$, Chen $H$, et al. Different clinical characteristics between perimesencephalic subarachnoid haemorrhage and diffuse subarachnoid haemorrhage with negative initial angiography. Turk Neurosurg. 2014;24(3):327-32.

35. Konczalla J, Platz J, Schuss P, Vatter H, Seifert V, Guresir $E$. Non-aneurysmal non-traumatic subarachnoid haemorrhage: patient characteristics, clinical outcome and prognostic factors based on a single-center experience in 125 patients. BMC Neurol. 2014;14:140.

36. Flaherty ML, Haverbusch M, Kissela B, Kleindorfer D, Schneider $A$, Sekar $P$, et al. Perimesencephalic Suba- rachnoid Haemorrhage: Incidence, Risk Factors, and Outcome. J Stroke Cerebrovasc Dis. 2005;14(6):267-71.

37. Lippincott's Nursing Procedures and Skills. Lippincott Williams \& Wilkins: 2010.

38. Burns JD, Huston J 3rd, Layton KF, Piepgras DG, Brown RD Jr. Intracranial Aneurysm Enlargement on Serial Magnetic Resonance Angiography Frequency and Risk Factors. Stroke. 2009;40(2):406-11.

39. Douds GL, Tadzong B, Agarwal AD, Krishnamurthy S, Lehman EB, Cockroft KM. Influence of Fever and Hospital-Acquired Infection on the Incidence of Delayed Neurological Deficit and Poor Outcome after Aneurysmal Subarachnoid Haemorrhage. Neurol Res Int. 2012;2012:479865.

40. Diepenbrock N. Quick Reference to Critical Care. 3rd ed. Philadelphia: Lippincott Williams \& Wilkins; 2008.

41. Jette DU, Latham NK, Smout RJ, Gassaway J, Slavin MD, Horn SD. Physical Therapy Interventions for Patients With Stroke in Inpatient Rehabilitation Facilities. Phys Ther. 2005;85(3):238-48.

42. Edlow JA, Fisher J. Diagnosis of Subarachnoid Haemorrhage. Diagnosis of subarachnoid hemorrhage: time to change the guidelines? Stroke. 2012;43(8):2031-2.

43. Jirkovský D. Nursing procedures and interventions. Prague: Fakultní nemocnice v Motole; 2014.

44. Mutoh T, Kazumata K, Terasaka S, Taki Y, Suzuki A, Ishikawa T. Early Intensive Versus Minimally Invasive Approach to Postoperative Hemodynamic Management After Subarachnoid Haemorrhage. Stroke. 2014;45(5):1280-4.

45. Laut J, Cappa F, Nov O, Porfiri M. Increasing Patient Engagement and Rehabilitation Exercises Using ComputerBased Citizen Science. PLoS One. 2015;10(3):e0117013. 


\section{Sažetak}

Subarahnoidna hemoragija stanje je izlijevanja krvi iz moždanih arterija u subarahnoidni prostor duž površine mozga. Subarahnoidna hemoragija (SAH) ima brojne etiološke mogućnosti, ali kada je riječ o spontanoj subarahnoidnoj hemoragiji, u $80 \%$ slučajeva uzrok joj je ruptura intrakranijske aneurizme. Subarahnoidna hemoragija može biti spontana i traumatska (posttraumatska). Također, može biti primarna ili sekundarna.

Inicijalna procjena bolesnika uključuje: pregled kvantitativnog stanja svijesti, veličinu zjenica i reakciju na svjetlost, motoričku i senzoričku funkciju, prisutnost glavobolje, disfunkciju kranijalnih živaca (ptoza kapaka, poteškoće pomicanja očiju u svim pravcima), zamagljen vid, afaziju, ostale neurološke deficite.

Nekoliko ozbiljnih komplikacija često nastaje nakon uspješne operacije subarahnoidne hemoragije i aneurizme. Jedna je takva komplikacija cerebralni vazospazam, a javlja se u 50 do 70 \% pacijenata. Odložene su komplikacije: recidivirajuće krvarenje, edem mozga, kronični hidrocefalus i kao najvažnija - infarkt mozga.

U monitoriranju te ovisno o nastalim komplikacijama, ali i u svim situacijama, uloga medicinske sestre prvenstveno se ogleda u praćenju vitalnih parametara i stanja svijesti te u prepoznavanju trenutaka nastanka klinički relevantne neurodeteriorijacije.

Ciljevi. Prikazati ukupan broj operiranih pacijenata $\mathrm{s}$ potvrđenom subarahnoidnom hemoragijom na Klinici za neurohirurgiju Kliničkog centra Univerziteta u Sarajevu u periodu od 1. siječnja 2013. do 31. prosinca 2014. Te prikazati: načine monitoriranja pacijenata od primitka u Kliniku do otpusta, stadije ishoda liječenja i indikatore kvalitete (ventilacijska pneumonija, intrahospitalne infekcije, dekubitusi) kod ispitivanog uzorka.

Metode. Provedena je retrospektivna studija. Učinjena je deskriptivno-analitička komparacija podataka iz povijesti bolesti i temperaturnih lista pacijenata koji su operirani na Klinici za neurohirurgiju Kliničkog centra Univerziteta u Sarajevu. Uzorak su činili paci- jenti oba spola s potvrđenom dijagnozom subarahnoidne hemoragije koji su operirani u Klinici u periodu od 1. siječnja 2013. do 31. prosinca 2014. Muškarci su bili zastupljeni s 50,7 \% ( $N=72$ ), a žene 49,3\% $(\mathrm{N}=70)$. Sudionici u studiji prosječne su dobi 54 godine, odnosno 45 - 63,2 godine.

Rezultati. Od 142 ispitanika u uzorku, 65,5 \% ih je hospitalizirano radi operacije aneurizmatskog, a 34,5 \% operiranih zbog neaneurizmatske subarahnoidne hemoragije. Ispitanici su prosječne dobi 54 godine. Muškarci su u prosjeku stari 53 godine, a žene 55 godina. Aneurizmatska subarahnoidna hemoragija bila je zastupljenija kod žena (65,6 \%). Ispitanici s neaneurizmatskom subarahnoidnom hemoragijom su stariji, u prosjeku u dobi od 61 (od 43 do 62) godine. Samo $2 \%$ ispitanika nakon operacije aneurizme nije bilo na neinvazivnom monitoringu, dok je udio takvih ispitanika nakon operacije neaneurizmatske subarahnoidne hemoragije znatno veći, 24,5\%.

Smrtni ishod bolesti imalo je ukupno 30 (32,6 \%) ispitanika operiranih zbog aneurizme, dok je taj postotak kod onih koji su operirani zbog neaneurizmatske bio manji i iznosi 8,2 \% (četiri ispitanika). Od preživjelih pacijenata, oni s aneurizmom u prosjeku su duže boravili u bolnici - 18 (12 do 24) dana. Od ukupnog broja operiranih zbog aneurizme $44(47,3 \%)$ je bilo samostalno pokretno nakon operacije, devet $(9,7 \%)$ ograničeno pokretno, osmero $(8,6 \%)$ je imalo vrlo ograničenu pokretljivost i $32(34,4 \%)$ je bilo nepokretno.

Većina ispitanika operiranih nakon $\mathrm{SAH}$-a samostalno je pokretna nakon operacije - 32 (65,3\%), 10 (20,4\%) ih je ograničeno pokretnih, troje $(6,1 \%)$ je imalo vrlo ograničenu pokretljivost i samo su četiri ispitanika $(8,2 \%)$ nepokretna. Od ukupnog uzorka - aneurizmatske subarahnoidne hemoragije ventilacijsku pneumoniju imalo je devet ispitanika $(9,7 \%)$ koji su podvrgnuti operaciji aneurizme, a dva (4,1 \%) bolesnika nakon operacije SAH-a.

Ključne riječi: subarahnoidna hemoragija, aneurizma, monitoring, neurokirurška sestra, poslijeoperacijska zdravstvena njega,vazospazam, bolničke infekcije i komplikacije 